\title{
The International Legal Obligations of States in Disputed Maritime Jurisdiction Zones and Prospects for Co-operative Arrangements in the East China Sea Region
}

\author{
David M. Ong
}

This article will first set out several observations on the politico-legal nature of the disputes over (island) territorial and overlapping maritime jurisdiction zones claimed from both these islands and mainland territory within the East Asian maritime region. It will then present arguments suggesting that the international legal implications of such disputes, whether territorial or maritime in nature, require the application of several significant international obligations by all States bordering the East China Sea and its associated maritime areas, including the Yellow Sea and the Sea of Japan/East Sea. For the purposes of this article, the East China Sea region will denote all these water bodies and the islands/rocks located within them.

II

\section{Territorial and Maritime East China Sea Disputes: Legal Implications}

Politically, there is a significant difference of perception both internationally and especially domestically, between the island and associated maritime jurisdiction disputes within the East China Sea. Specifically, international disputes over insular formations are often initially expressed and in time become fixated within the domestic political/social consciousness of littoral States as an overriding issue of national pride. Where these disputes concern sovereignty over island territories, such as the Dioayutai/Senkaku and Dokdo/Takeshima ${ }^{1}$

1 The Japanese perspective on this disputed island (Takeshima/Dokdo) is accessible at the website of the Japan Ministry of Foreign Affairs (MOFA), available at http://www.mofa.go.jp/ region/asia-paci/takeshima/index.html. 
disputes, they are significantly more intractable to resolve under international law. They also require the application of general public international law principles, in addition to those found in the 1982 United Nations Convention on the Law of the Sea (UNCLOS). The law of the sea and specifically unCLOS plays a role in the delimitation, rights and responsibilities in the maritime jurisdiction zones generated from these insular formations, notably, the territorial sea, continental shelf and Exclusive Economic Zone (EEZ), but not the sovereignty over these islands. The UNCLOS, specifically Articles 74(3) and 83(3) are applicable when the unresolved sovereignty issue extends to the maritime jurisdiction zones claimed by the respective States from these islands or rocks, ${ }^{2}$ as well as the overlapping continental shelves and EEzs claimed from the mainland and (in the case of Japan) the main island coastlines. There is increasing evidence that the political and legal distinctions highlighted above over territorial (island) disputes, as opposed to disputes over the maritime jurisdiction claims arising from either these islands, or the mainland/main island coastlines of the States themselves, are being recognised. For example, Gong has recently noted that the Sino-Japanese maritime disputes in the East China Sea concern two issues: the territorial sovereignty of the Diaoyu/Senkaku islands and maritime delimitation, with the sovereignty dispute over the Diaoyu islands traditionally being the key factor in the East China Sea. Thus, he argues that if this dispute can be disentangled from the maritime delimitation issue through an agreement to exclude the Diaoyu/Senkaku islands from generating continental shelf or EEZs, then the maritime delimitation issue might be handled more easily, since most confrontations and reciprocal distrust to date are rooted in the sovereignty dispute. According to Gong, resolution to the delimitation issue within the East China Sea region will likely take the form of further negotiations towards a maritime delimitation agreement involving possible joint development of resources, or a judicial settlement. While the 2008 China-Japan Principled Consensus on the East China Sea issue is a major step toward cooperation on maritime energy resources, further compromise is required. If China and Japan cannot reach a consensus on the scope of the disputed waters, a judicial settlement may provide another option for settling disputes. The policy implications of Gong's analysis are, inter alia, if the sovereignty dispute over the Diaoyu/ Senkaku islands continues to remain unresolved then confrontations over the sovereignty of the islands will very likely escalate. China and Japan should therefore agree to exclude the Diaoyu/Senkaku islands from generating EEZ or continental shelf claims to facilitate a resolution of the maritime delimitation

2 Both Article 121(3) of UNCLOS and recent international jurisprudence indicate that rocks which are incapable of sustaining human habitation cannot be allowed to generate maritime jurisdiction space further than the $12 \mathrm{~nm}$ territorial sea limits. 
issue. If both countries effectively promote the 2008 Principled Consensus, then the establishment of joint development zones near the Diaoyu/Senkaku islands could accelerate the process of cooperation. Finally, the two countries need to be flexible on the method of dispute settlement. A clearly delimited maritime boundary reached through a judicial settlement or further sincere negotiations would encourage Sino-Japanese cooperation in scientific research, environmental protection, and other issues in the East China Sea. ${ }^{3}$

Given the fact that none of the island territorial sovereignty issues are likely to be submitted before any judicial forms of dispute resolution soon, ${ }^{4}$ the legal focus shifts to the overlapping maritime jurisdiction zones, whether claimed from the respective mainland territories of the interested States or the disputed island territories between them. Specifically, it should be noted that the international law of the sea makes a distinction between the legal entitlement of coastal/island States to their adjacent seabed or continental shelf jurisdiction, and their delimitation as between their equally entitled neighboring States. Albeit pursuant to the further question of the entitlement of Bangladesh and Myanmar (Burma) respectively, to continental shelves beyond 200-nautical miles, the International Tribunal on the Law of the Sea (ITLOS) has recently confirmed that:

A coastal State's entitlement to the continental shelf exists by the sole fact that the basis of entitlement, namely, sovereignty over the land territory, is present. It does not require the establishment of outer limits. Article 77, paragraph 3, of the Convention, confirms that the existence of entitlement does not depend on the establishment of the outer limits of the continental shelf by the coastal State. ${ }^{5}$

Applying this generally to seabed areas beyond the 200-nm limit from coastlines, the Tribunal further held that: "Entitlement to a continental shelf beyond $200 \mathrm{~nm}$ should thus be determined by reference to the outer edge of the continental margin, to be ascertained in accordance with Article 76 ,

3 Gong Yingchun, The Development and Current Status of Maritime Disputes in the East China Sea, in The (US) National Bureau of Asian Research, Maritime Energy ReSources in Asia: Energy and Geopolitics (December 2011).

4 Following the most recent spate over the sovereignty of the Dokdo/Takeshima islands between the Republic of (South) Korea and Japan in July-August 2012, the Korean government has rebuffed a proposal by the Japanese Ministry of Foreign Affairs (MOFA) to submit the dispute to the ICJ. This follows similar proposals by Japan in the 1950s and 1960s, which have each time been refused by Korea.

5 Dispute concerning delimitation of the maritime boundary between Bangladesh and Myanmar in the Bay of Bengal (Bangladesh/Myanmar) IT Los Judgment (2011), at para. 409. 
paragraph 4. To interpret otherwise is warranted neither by the text of Article 76 nor by its object and purpose." 6

Finally, applying these general analytical determinations to the case before it, the ITLOS made the following observations: "The Tribunal therefore cannot accept Bangladesh's contention that, by reason of the significant geological discontinuity dividing the Burma plate from the Indian plate, Myanmar is not entitled to a continental shelf beyond $200 \mathrm{~nm} .{ }^{.7}$ Summing up the case before it, the ITLOS Judgment stated that the "Tribunal is not convinced by the arguments of Bangladesh that Myanmar has no entitlement to a continental shelf beyond $200 \mathrm{~nm}$. The scientific data and analyses presented in this case, which have not been contested, do not establish that Myanmar's continental shelf is limited to $200 \mathrm{~nm}$ under Article 76 of the Convention, and instead indicate the opposite. ${ }^{8}$ The Tribunal accordingly concludes that both Bangladesh and Myanmar have entitlements to a continental shelf extending beyond $200 \mathrm{~nm}$. The submissions of Bangladesh and Myanmar to the Commission clearly indicate that their entitlements overlap in the area in dispute in this case." 9

The implications of the above statements for the dispute between China and Japan over the significance of the Okinawa Trough as a natural break in the seabed prolongation of land territory from both Chinese mainland territory and the main Japanese islands are far-reaching. Gao for example has noted that there are two aspects to the controversy over the Okinawa Trough between the States bordering the East China Sea. The scientific aspect concerns whether the Okinawa Trough disrupts the unity of the continental shelf in the East China Sea, and the legal aspect concerns whether geophysical factors should be considered in the delimitation between opposite States where the distance between their coasts is less than 400 nautical miles. He argues that if the Okinawa Trough is proved to constitute a fundamental discontinuity between the natural prolongation of China and Korea on the one hand, and that of Japan on other hand, the median line between the opposite coasts concerned should not be applied in the continental shelf delimitation, for it cannot achieve an equitable solution, ${ }^{10}$ as required by Articles $83(1)$ and $74(1)$ of unCLOS. However, China's long-standing view that the Trough represents the furthermost limits of the Japanese legal continental shelf facing the Chinese mainland is arguably diminished by the recent ITLOs finding.

\footnotetext{
$6 \quad$ Ibid., at para. 437 .

$7 \quad$ Ibid., at para. 438 .

$8 \quad$ Ibid., at 130, para. 448.

$9 \quad$ Ibid., at 131, para. 449.

10 Jianjun Gao, The Okinawa Trough Issue in the Continental Shelf Delimitation Disputes within the East China Sea, 9 (1) Chinese Journal of International LAW 143-177 (2010).
} 
More generally, the above extracts of the ITLOS jurisprudence strongly suggest that notwithstanding the continuing island/rock territorial disputes, all the interested States in the East China Sea region, namely, North and South Korea, as well as China and Japan have legal entitlements to continental shelf rights up to at least 200-nm (and possibly further) without needing to rely on the ostensible maritime jurisdiction zones generated from the disputed islands/rocks themselves. This leads to the conclusion that all the main protagonists in this scenario have legitimate interests in the seabed between their main (land/island) coastlines and around the disputed island territories, notwithstanding the lack of resolution of the latter disputes. As the law, like nature, abhors a vacuum, the question that then arises is as follows: What are the international rights and obligations of the States involved in the East China Sea region, both specifically under the UNCLOS as well as general international law? Thus, the scene is set for a consideration of these specific procedural and substantive rights and obligations, as well as their normative status in relation to the States in this region.

III

\section{Procedural Obligations of Notification, Information, Consultation and EIA}

We will begin with the procedural rights and obligations between States in this maritime region. Developments in international law and especially international environmental law, recently confirmed by relevant international jurisprudence, arguably point to an increasingly sophisticated set of procedural standards of behaviour applicable to the States in this region. This section of the article will therefore highlight recent international legal developments on shared natural resource issues and/or transboundary environmental problems, with a view to examining their application to the possible resolution of East China Sea maritime disputes.

Here, it has been noted that the evolving standards of State behaviour have focused upon requirements of prior notification, information and consultation (NIC) with respect to hazardous activities conducted within their territories which may cause damage, either to the territories of other States, or areas beyond national jurisdiction. ${ }^{11}$ Moreover, the procedural obligation to

11 David M. Ong, Procedural International Environmental Justice? The Evolution of Procedural Means for Environmental Protection: From Inter-State Obligations to Individual-State Rights, in Duncan French (ed.) Global Justice And Sustainable Development 137-166, 141 (2010). 
notify, inform and consult (NIC) between States, as an accompaniment to the substantive obligation not to cause transboundary environmental damage, both generally and especially in respect of potentially hazardous activities, has arguably been confirmed by the jurisprudence of international tribunals as being part of customary international law long before its inclusion within more recent treaty instruments. As Louka notes, for example, "[t]he Lac Lanoux case has been heralded as establishing the principle of prior consultation with another (S)tate before undertaking a project that has transboundary effects. Such a principle has been repeated in a number of international instruments, including the (Transboundary) Environmental Impact Assessment (EIA) Convention."12 Further international case law has both confirmed and expanded upon these procedural obligations of notification, information and consultations on both transboundary environmental concerns and shared natural resources issues.

\section{A Malaysia/Singapore Land Reclamation case (2001) before ITLos}

For example, under the auspices of UNCLOS, the ITLOS and other related (Annex VII) arbitral tribunal decisions have arguably elaborated upon the requirement of notification, information and consultation prior to undertaking potentially hazardous activities in frontier areas between States. Thus, in the Land Reclamation case between Malaysia and Singapore, the ITLOS undertook to prescribe what has been described as a "constrained bilateral negotiations procedure" for both Parties. ${ }^{13}$

This constrained bilateral negotiations procedure incorporated specific notification, information and consultation (NIC) requirements with respect to the potential impact of large scale land reclamation activities undertaken by Singapore within her own territorial waters upon neighbouring Malaysian coastal interests and the ecosystem quality of the surrounding marine environment. The ITLOs Order unanimously held, inter alia, that Malaysia and Singapore shall first cooperate and enter into consultations to establish promptly a group of independent experts with a mandate to conduct a study to determine the effects of Singapore's land reclamation and to propose, as appropriate, measures to deal with any adverse effects of such land reclamation; exchange,

12 E. Louka, International Environmental LaW 42 (2006) 42, citing para. 24 of the Lac Lanoux Arbitration case (France v. Spain) 16 November 1957, 12 RIAA 281. Convention on Environmental Impact Assessment in a Transboundary Context of the United Nations Economic Commission for Europe, 25 February 1991, 1989 UnTs 309 (entered into force 10 September 1997) [hereinafter, "Espoo Convention"].

13 Case Concerning Land Reclamation by Singapore in and around the Straits ofJohor (Malaysia v. Singapore), Request for Provisional Measures, Order, 8 October 2003, IT LOs Case No. 12. 
on a regular basis, information on, and assess risks or effects of, Singapore's land reclamation works; and implement the commitments noted in this Order, and avoid any action incompatible with their effective implementation. Finally, without prejudice to their positions on any issue before the Annex VII arbitral tribunal, the Parties were to consult with a view to reaching a prompt agreement on such temporary measures. ${ }^{14}$ More substantively, the Tribunal also directed Singapore not to conduct its land reclamation in ways that might cause irreparable prejudice to the rights of Malaysia or serious harm to the marine environment, taking especially into account the reports of the group of independent experts.

Subsequently, the Arbitral Tribunal established under Annex VII of UNCLOS convened to decide the merits of the above case and was inveighed by the two Parties to accept a Settlement Agreement incorporating the Recommendations by the Group of Experts ( $\mathrm{GOE}$ ) established pursuant to the (above) ITLos Order, and adopted by the two States. Within this Settlement Agreement, the Parties agreed to expand the terms of reference of the Malaysia-Singapore Joint Committee on the Environment (MSJCE) to exchange information on and discuss matters affecting their respective environments in the Straits of Johor, as well as undertake monitoring activities in relation to their respective environments in the Straits of Johor and address any adverse impacts, if necessary. These monitoring activities were to include: (i) monitoring water quality to protect the marine and estuarine environment; and (ii) monitoring ecology and morphology. ${ }^{15}$

\section{B Argentina/Uruguay Pulp Mills case (2007 and 2010) before the ICJ}

The ICJ has also recently rendered a decision in the Pulp Mills case between Argentina and Uruguay that is at least in part about the extent of an international duty between neighboring States across a common river boundary, to notify, inform and consult each other about proposed activities that have potentially serious transboundary impacts. ${ }^{16}$ In the opinion of the Court, "the obligation to notify is intended to create the conditions for successful co-operation between the parties, enabling them to assess the plan's impact on the river on the basis of the fullest possible information and, if necessary, to negotiate the

14 Ibid. at para. 106 of the ITLOS Order.

15 Annex to Settlement Agreement in Case Concerning Land Reclamation by Singapore in and around the Straits of Johor (Malaysia v. Singapore). Done in duplicate at Singapore, 26 April 2005. Available at www.mfa.gov.sg/internet/press/land/Settlement_Agreement.pdf.

16 Case Concerning Pulp Mills on the River Uruguay (Argentina v. Uruguay) Judgment, 20 April 2010, available at http://www.icj-cij.org/docket/files/135/15877.pdf. 
adjustments needed to avoid the potential damage that it might cause."17 The Court therefore concluded that "the obligation to notify is therefore an essential part of the process leading the parties to consult in order to assess the risks of the plan and to negotiate possible changes which may eliminate those risks or minimize their effects." ${ }^{18}$

Having established that Uruguay breached its procedural obligations to inform, notify and negotiate, ${ }^{19}$ the Court turned to the relationship between the need for an environmental impact assessment, where the planned activity is liable to cause harm to a shared resource and transboundary harm. ${ }^{20}$ Here, the ICJ ruled that "it may now be considered a requirement under general international law to undertake an environmental impact assessment (EIA) where there is a risk that the proposed industrial activity may have a significant risk in a transboundary context, in particular, on a shared resource."21 The Court noted that "the environmental impact assessments which are necessary to reach a decision on any plan that is liable to cause significant transboundary harm to another State must be notified by the party concerned to the other party, ... to enable the notified party to participate in the process of ensuring that the assessment is complete, so that it can then consider the plan and its effects with a full knowledge of the facts". ${ }^{22}$ The Court observed that this notification must take place before the State concerned decides on the environmental viability of the plan, taking due account of the environmental impact assessment submitted to it. ${ }^{23}$

The Court concluded that Uruguay had failed to fulfil her procedural obligation to notify and allow Argentina to participate in the transboundary EIA exercise prior to approving the proposed projects. ${ }^{24}$ It was the opinion of the Court that the Parties must, for the purposes of protecting and preserving the aquatic environment with respect to activities which may be liable to cause transboundary harm, carry out an environmental impact assessment, stating that: "In this sense, the obligation to protect and preserve has to be interpreted in accordance with a practice, which in recent years has gained so much acceptance among States that it may now be considered a requirement under general international law to undertake an environmental impact assessment

\footnotetext{
17 Ibid., at para. 113.

18 Ibid., at para. 115 .

19 Ibid., at para. $15^{8}$.

$20 \quad$ Ibid., at para. 203.

21 Ibid., at 60-61, para. 204.

$22 \quad$ Ibid., at para. 119.

23 Ibid., at para. 120.

24 Ibid., at para. 122.
} 
where there is a risk that the proposed industrial activity may have a significant adverse impact in a transboundary context, in particular, on a shared resource." 25 Moreover, in the opinion of the Court, as long as the procedural mechanism for co-operation between the parties to prevent significant damage to one of them is taking its course, the State initiating the planned activity is obliged not to authorize such work and, a fortiori, not to carry it out. ${ }^{26}$ Consequently, due diligence, and the duty of vigilance and prevention which it implies, would not be considered to have been exercised, if a (State) party planning works liable to affect the regime of the river or the quality of its waters did not undertake an environmental impact assessment on the potential effects of such works. ${ }^{27}$

On the other hand, the Court agreed with the Uruguayan assertion that one party did not have a "right of veto" over the projects initiated by the other, such that there was a "no construction obligation" borne by the State initiating the projects until such time as the Court has ruled on the dispute. ${ }^{28}$ Uruguay pointed out that the existence of such an obligation would enable one party to block a project that was essential for the sustainable development of the other, something that would be incompatible with the "optimum and rational utilization of the [r]iver" - the shared natural resource in question here. For Uruguay, reference should be made to general international law, as reflected in the 2001 draft Articles of the International Law Commission on Prevention of Transboundary Harm from Hazardous Activities (Yearbook of the International Law Commission, 2001, Vol. II, Part Two); in particular, draft Article 9, paragraph 3, concerning "Consultations on preventive measures", states that "[i]f the consultations ... fail to produce an agreed solution, the State of origin shall nevertheless take into account the interests of the State likely to be affected in case it decides to authorize the activity to be pursued."29

However, on the specific requirements and standard of protection of the obligation to conduct a transboundary EIA, the Court also observed that general international law does not specify the scope and content of an environmental impact assessment. Moreover, it pointed out that Argentina and Uruguay are not parties to the Espoo Convention. Consequently, it is the view of the Court that it is for each State to determine in its domestic legislation or in the authorization process for the project, the specific content of the environmental

\footnotetext{
25 Ibid., at para. 204 .

26 Ibid., at para. 144.

27 Ibid., at para. 204.

$28 \quad$ Ibid., at para. 154 .

$29 \quad$ Ibid., at para. $15^{2}$.
} 
impact assessment required in each case, having regard to the nature and magnitude of the proposed development and its likely adverse impact on the environment as well as to the need to exercise due diligence in conducting such an assessment. ${ }^{30}$

Finally, the Court noted that the other instrument to which Argentina refers in support of its arguments, namely, the 1987 Goals and Principles of Environmental Impact Assessment of the United Nations Environment Programme (hereinafter, "Unep Goals and Principles") (UNEP/WG.152/4 Annex (1987), document adopted by UNEP Governing Council at its 14th Session (Dec. 14/25 $(1987)$ ), is not binding on the Parties, but, as guidelines issued by an international technical body, has to be taken into account by each Party in accordance with Article 41 (a) in adopting measures within its domestic regulatory framework. Moreover, this instrument provides only that the "environmental effects in an EIA should be assessed with a degree of detail commensurate with their likely environmental significance" (Principle 5) without giving any indication of minimum core components of the assessment. The Court also considered that an environmental impact assessment must be conducted prior to the implementation of a project. Moreover, once operations have started and, where necessary, throughout the life of the project, continuous monitoring of its effects on the environment shall be undertaken. ${ }^{31}$

As the Court had already considered the role of environmental impact assessment in the context of the procedural obligations of the Parties, it then dealt with the specific points in dispute with regard to the role of this type of assessment in the fulfilment of the substantive obligations of the Parties, inter alia, whether the populations likely to be affected, in this case both the Uruguayan and Argentine riparian populations, should have, or have in fact, been consulted in the context of environmental impact assessment. ${ }^{32}$ While both Parties agree that consultation of the affected populations should form part of an environmental impact assessment, Argentina asserts that international law imposes specific obligations on States in this regard. In support of this argument, Argentina points to Articles 2.6 and 3.8 of the Espoo Convention, Article 13 of the 2001 International Law Commission draft Articles on Prevention of Transboundary Harm from Hazardous Activities, and Principles 7 and 8 of the UNEP Goals and Principles. Uruguay considered that the provisions invoked by Argentina cannot serve as a legal basis for an obligation to consult the affected populations and adds that in any event the affected populations had

$30 \quad$ Ibid., at para. 205 .

$31 \quad$ Ibid.

$32 \quad$ Ibid., at para. 206. 
indeed been consulted. ${ }^{33}$ The Court agreed and was of the view that no legal obligation to consult the affected populations arises for the Parties from the instruments invoked by Argentina. ${ }^{34}$ In any case, having considered Uruguay's efforts in this regard, the Court held that consultation by Uruguay of the affected populations did indeed take place. ${ }^{35}$

\section{State Responsibility for Sponsored Activities in the (Deep Seabed) Area: Advisory Opinion by the ITLOS Seabed Disputes Chamber (2011)}

Apart from the binding decisions (for the States involved) of the judicial decisions above, the ITLOS Seabed Disputes Chamber has also recently rendered an authoritative, albeit non-legally binding advisory opinion on the applicable international law and especially, international environmental law principles applicable to the States that oversee the activities of legal persons or entities within the deep seabed area, ${ }^{36}$ beyond the limits of national jurisdiction. Among the most important of these direct obligations incumbent on sponsoring States are as follows: the obligation to assist the Authority in the exercise of control over activities in the Area; the obligation to apply a precautionary approach; the obligation to apply best environmental practices; the obligation to take measures to ensure the provision of guarantees in the event of an emergency order by the Authority for protection of the marine environment; the obligation to ensure the availability of recourse for compensation in respect of damage caused by pollution; and the obligation to conduct environmental impact assessments. ${ }^{37}$ The Chamber stressed that the obligation to conduct an environmental impact assessment is a direct obligation under the Convention and a general obligation under customary international law. ${ }^{38}$ The Chamber then reiterated Article 206 of UNCLOS, which states the following:

When States have reasonable grounds for believing that planned activities under their jurisdiction or control may cause substantial pollution of or significant and harmful changes to the marine environment, they shall, as far as practicable, assess the potential effects of such activities

\footnotetext{
$33 \quad$ Ibid., at para. 215 .

$34 \quad$ Ibid., at para. 216.

$35 \quad$ Ibid., at para. 219.

${ }_{3} 6$ Responsibilities And Obligations Of States Sponsoring Persons And Entities With Respect To Activities In The Area, Seabed Disputes Chamber of the International Tribunal for the Law of the Sea, Advisory Opinion, ITLOS Case List No.17, 1 February 2011.

37 Ibid., at 38, para. 122.

38 Ibid., at 44 , para. 145 .
} 
on the marine environment and shall communicate reports of the results of such assessments in the manner provided in article 205 (which refers to an obligation to publish reports). ${ }^{39}$

Referring directly to paragraph 204 of the ICJ Judgment in the Pulp Mills case, the Chamber noted the assertion by the ICJ that "it may now be considered a requirement under general international law to undertake an environmental impact assessment where there is a risk that the proposed industrial activity may have a significant adverse impact in a transboundary context, in particular, on a shared resource. ${ }^{\prime 40}$ Significantly for our purposes in the present article arguing for the application of this principle in the East China Sea, the Chamber noted that: "Although aimed at the specific situation under discussion by the Court, the language used seems broad enough to cover activities in the Area even beyond the scope of the Regulations. The Court's reasoning in a transboundary context may also apply to activities with an impact on the environment in an area beyond the limits of national jurisdiction; and the Court's references to "shared resources" may also apply to resources that are the common heritage of mankind. Thus, in light of the customary rule mentioned by the ICJ, it may be considered that environmental impact assessments should be included in the system of consultations and prior notifications set out in Article 142 of the Convention with respect to "resource deposits in the Area which lie across limits of national jurisdiction".41

However, the Chamber also observed that, in the view of the ICJ, general international law does not "specify the scope and content of an environmental impact assessment" (paragraph 205 of the Judgment in Pulp Mills on the River Uruguay). While Article 206 of the Convention gives only few indications of this scope and content, the indications in the Regulations, and especially in the Recommendations referred to in paragraph 144 , add precision and specificity to the obligation as it applies in the context of activities in the Area. ${ }^{42}$ In light of the above, the Chamber is of the view that the obligations of the contractors and of the sponsoring States concerning environmental impact assessments extend beyond the scope of application of specific provisions of the Regulations. ${ }^{43}$

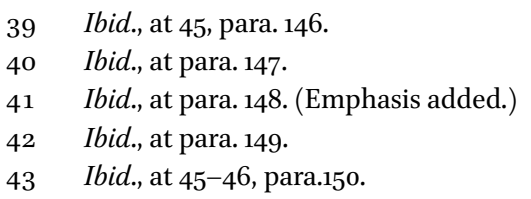




\section{Specific Procedural Obligations over Hydrocarbon Deposits in Disputed Maritime Areas}

\section{A}

Guyana-Suriname Maritime Boundary Delimitation Award by an Arbitral Tribunal established under Annex VII of the UNCLOS (2007)

Within the context of shared natural resources, rather than transboundary environmental damage, another UNCLOS Annex VII arbitral tribunal award rendered between Guyana and Suriname in 2007 also prescribed a negotiation process involving detailed notification, information disclosure and consultation requirements for the State initiating offshore hydrocarbon exploration activities within an overlapping continental shelf claims area of the seabed, under Articles 74(3) and 83(3) of UnCLOs. ${ }^{44}$ A continuing issue in the evolving international law on offshore joint development of shared hydrocarbon resources relates to the scope of the actions that States can undertake when it becomes clear that a seabed area the State regards as within its continental shelf entitlement is also part of an overlapping claims area. In this context, two developments in judicial opinion and State practice may be highlighted. First, it is suggested here that the 2007 Guyana/Suriname Award ${ }^{45}$ deals with the procedural elements for co-operation embodied in Articles 74(3) and 83(3) of UNCLOS in such a way as to considerably reduce the scope for any unilateral action by interested States in a disputed maritime area, where hydrocarbon resources have been detected. This Award first declares that these Articles impose two obligations which according to the Tribunal 'simultaneously attempt to promote and limit activities in a disputed maritime area. ${ }^{46}$ The first requirement is that pending the final delimitation agreement, States Parties are to make "every effort to enter into provisional arrangements of a practical nature." 47 The second obligation is that the Parties must during this transitional period also make every effort not to jeopardize or hamper the reaching of the final delimitation agreement. ${ }^{48}$

In relation to the first obligation contained within these Articles, the Tribunal was of the view that it was intended to promote the provisional utilization

44 See, Guyana v. Suriname, unclos Annex Vir Arbitral Tribunal Award (2007) available at www.pac-cpa.org.

45 Guyana/Suriname, Award of Arbitral Tribunal established pursuant to Article 287 and Annex VII of the 1982 United Nations Convention on the Law of the Sea (UNCLOS) on 17 September 2007, available at http://www.pca-cpa.org/.

$46 \quad$ Ibid., at 152 , para. 459 .

47 Ibid.

$48 \quad$ Ibid., at 153 , para. 459 . 
of natural resources within disputed maritime areas, pending their delimitation. Thus, according to the Tribunal, 'this obligation constitutes an implicit acknowledgement of the importance of avoiding the suspension of economic development in a disputed maritime area, as long as such activities do not affect the reaching of a final agreement. ${ }^{\prime 9}$

Applying these findings to the East China Sea region, while China began exploring for oil and gas in 1974, Japan refrained from licensing such activities (with the exception of the exploration under the 1974 Japan-RoK treaty) until 2004. China moved ever closer to the median line which Japan proposed after both countries had ratified UNCLOS in 1996, and at times even went over to the Japanese side of it. According to Drifte, these two countries missed opportunities to deal with the territorial and boundary disputes while oil and gas interest were not yet very important and while Japan had a technological edge over China in deep-sea oil exploration. By refraining from any exploration itself, Japan sent misleading messages to the Chinese side. The most misleading Japanese action was co-financing of Chinese activities in disputed areas of the EEZ in the 1990s: In November 1998, China had begun full operation of its first oil and natural gas field in the Pinghu field, about $70 \mathrm{~km}$ from the median line, on the Chinese side. In 1997/98 Japan co-financed - through its contribution to the Asian Development Bank (ADB), as well as directly through its Export Import Bank (renamed Japan Bank of International Cooperation in 1999) - the two oil and gas pipelines from the Pinghu field to the Chinese mainland. The initial disbursement by the ADB was in February 1997, and the final one was as recent as November 2001 (ADB 2004). This support of Chinese oil and gas extraction activities in the contested area has received heavy criticism in Japan in recent years. Today, the Japanese government publicly insists that the Pinghu field is within the contested ECS area, as long as no agreement on the demarcation has been reached, because it lies within $200 \mathrm{n} . \mathrm{m}$. from the Japanese mainland (YS, 28/4/05, 9/11/06). The Pinghu pipelines have now also come under suspicion because China has connected them with those of the Chunxiao field. Seen from a Chinese perspective, however, the long-term Japanese tolerance and even financial support must have been interpreted as at least implicit acquiescence regarding China's rights in the area, as long as China's activities did not fall within any area on the Japanese side of the median line. ${ }^{50}$

The Tribunal also noted that such provisional arrangements would achieve one of the UNCLOS objectives, namely, "the equitable and efficient utilization

49 Ibid., at 153, para. 460.

5o Reinhard Drifte, Territorial Conflicts in the East China Sea-From Missed Opportunities to Negotiation Stalemate (2009), available at http://www.japanfocus.org/-Reinhard-Drifte/3156. 
of the resources of the seas and oceans."51 Focusing on the normative density of this first obligation, the Tribunal noted that despite the fact that the phrase "every effort" leaves room for interpretation by the interested States or any dispute settlement body, "it is the opinion of the tribunal that the language in which the obligation is framed imposes on the Parties a duty to negotiate in good faith." 52 The Tribunal buttresses this finding by suggesting that the inclusion of the phrase "in a spirit of understanding and co-operation", indicates the drafters' intent to require of the parties a conciliatory approach to negotiations, pursuant to which they would be prepared to make concessions in the pursuit of a provisional arrangement."53 This allusion to the intentions of the parties to UNCLOS is returned to by the Tribunal later on in the Award when it notes that: "Provisional arrangements of a practical nature have been recognized as important tools in achieving the objectives of the Convention, and it is for this reason that the Convention imposes an obligation on parties to a dispute to make every effort to reach such agreements." 54

Thus, the Tribunal placed a specific obligation upon Guyana to inform Suriname directly of Guyanese plans to allow its concessionaire company, CGX, to undertake exploratory drilling. ${ }^{55}$ In an unprecedented move, the Tribunal then specified the precise steps that Guyana could have taken that would have been consistent with her obligations under the Convention and thus sufficient to discharge her duty to make every effort to reach a provisional agreement. These steps "include (1) giving Suriname official and detailed notice of the planned activities, (2) seeking (the) co-operation of Suriname in undertaking the(se) activities, (3) offering to share the results of the exploration and giving Suriname an opportunity to observe the activities, and (4) offering to share all the financial benefits received from the exploratory activities." ${ }^{56}$ By providing this detailed exposition of the required notification, information-sharing, and consultation process that the interested States must enter into, the Tribunal has clearly established the legally authoritative standards of behaviour for any State finding itself in a similar situation where it is seeking to initiate exploration activities, either in respect of a transboundary deposit or overlapping claims area. In doing so, the Tribunal has also clearly drawn from, and analogously applied, the prior notification requirement incumbent upon the

\footnotetext{
$5^{1} \quad$ Ibid., citing the Preamble to UnCLOS, where this term can be found in the 4 th indent.

$5^{2} \quad$ Ibid., para. 461 .

53 Ibid. This term does replicate almost word for word: 'in a spirit of mutual understanding and co-operation,' the very first indent of the Preamble to UnCLOS.

54 Ibid., at 154, para. 464.

55 Ibid., at $159-160$, para. 477 .

56 Ibid., para. 477 , at 160 of the Award.
} 
International Seabed Authority (ISA) in similar situations of mineral deposits lying across the limits of national jurisdiction and the deep seabed Area, under Article 142(2) of UNCLOS. ${ }^{57}$ Within this context, the Tribunal's advocacy (in step (4), above) of the sharing of any benefits derived from exploration activities is both useful as well as arguably establishing a clear legal presumption for the joint development (and revenue-sharing) of any hydrocarbon deposits found in a disputed maritime area.

Applying these legal standards to the disputes of the East China Sea region, it should be noted that in 2003 the Japanese government began to ask the Chinese to hand over data hydrocarbon exploration and production activities in the Chunxiao field area. Beijing refused since it considers the area part of its EEZ. In order to enhance its leverage, the Japanese government decided in 2004 to collect its own geological information. From July to October 2004, a private company commissioned by the Energy Agency of Ministry of Energy, Trade and Industry (METI) conducted a geological survey on the Japanese side of the median line, in order to investigate whether China was tapping into gas reserves which straddle the median line. The survey area was a $210 \mathrm{~km}$ northsouth strip, with a width of $30 \mathrm{~km}$, the lower end facing the Chunxiao and Tianwaitian gas fields on the Chinese side (Map in Kaijō Hōan Repōto 2006: 38). China reacted immediately after the announcement of the survey and warned the Japanese to act with caution in what it considered to be the Chinese EEZ (FMPRC 2004). It was even reported that a Chinese surveillance vessel, and later two warships, tried to chase away the survey ship (AS, 13/10/04; YS, 13/4/05). The interim report of the survey, in February 2005, concluded that it was highly likely that the Chunxiao and Duanqiao geological structures were linked with those on the Japanese side of the median line; this was confirmed as definite in the final report in April 2005 (YS, 2/4/05). The Chinese disputed any geophysical link between the two sides, maintaining that the geological faults near the two gas fields prevent such a link (YS, 21/2/05). 58

B

Recent Provisions from Bilateral Boundary Agreements: NorwayRussia Maritime Delimitation (2010)

These detailed notification and consultation requirements can be also be discerned in recent State practice, namely, the Treaty between the Kingdom of Norway and the Russian Federation concerning Maritime Delimitation and

57 See, David M. Ong, Joint Development of Common Offshore Oil and Gas Deposits: 'Mere' State Practice or Customary International Law?, 93 AmeriCAN Journal of InternaTIONAL LAW 771-804, 785 (1999) and Cameron (2006) op. cit., at 567.

58 Reinhard Drifte, Territorial Conflicts in the East China Sea-From Missed Opportunities to Negotiation Stalemate (2009) available at http://www.japanfocus.org/-Reinhard-Drifte/3156. 
Cooperation in the Barents Sea and the Arctic Ocean, adopted in Murmansk on 15 September 2010.59 Para. 2 of Article 5, along with Appendix II of this Treaty, provides for a specific procedure to deal with transboundary hydrocarbon deposits lying across the recently agreed maritime boundary, as follows:

If the existence of a hydrocarbon deposit on the continental shelf of one of the Parties is established and the other Party is of the opinion that the said deposit extends to its continental shelf, the latter Party may notify the former Party and shall submit the data on which it bases its opinion.

If such an opinion is submitted, the Parties shall initiate discussions on the extent of the hydrocarbon deposit and the possibility for exploitation of the deposit as a unit.

In the course of these discussions, the Party initiating them shall support its opinion with evidence from geophysical data and/or geological data, including any existing drilling data and both Parties shall make their best efforts to ensure that all relevant information is made available for the purposes of these discussions.

If the hydrocarbon deposit extends to the continental shelf of each of the Parties and the deposit on the continental shelf of one Party can be exploited wholly or in part from the continental shelf of the other Party, or the exploitation of the hydrocarbon deposit on the continental shelf of one Party would affect the possibility of exploitation of the hydrocarbon deposit on the continental shelf of the other Party, agreement on the exploitation of the hydrocarbon deposit as a unit, including its apportionment between the Parties, shall be reached at the request of one of the Parties (hereinafter "the Unitisation Agreement") in accordance with Annex II.

A summary of the procedural obligations under international law applicable to all interested States in the East China Sea region is as follows:

1. Duty to inform and consult other interested States addressing the possible impacts on freedom of navigation and other user activities, over all planned activities that may have implications for sovereignty over the disputed islands, and/or sovereign rights and jurisdiction in the disputed maritime zones, whether these are military, research and/or exploration activities, or building activities on any insular formations.

2. Duty to conduct an EIA for such activities, assessing the possible social, environmental and ecological concerns;

59 Norwegian Ministry of Foreign Affairs official website, available at http://www.regjeringen.no/upload/UD/Vedlegg/Folkerett/avtale_engelsk.pdf. 
3. For the specific issue of hydrocarbon fields/deposits found either within areas of overlapping seabed claims, or lying across previously delimited maritime boundaries, the procedural duties of both negotiation towards an interim/provisional (co-operative) agreement and restraint from unilateral drilling of such fields/deposits, even for exploratory purposes, has also been confirmed by successive international jurisprudence and recent State practice on this issue.

There is evidence that such procedural standards of notification are being established in the East China Sea region. This derives from littoral State practice responding to incidents involving research vessels in the Sino-Japanese areas of overlapping claims. The two nations agreed on 31 August 2000 to negotiate an agreement for advance notification of such "surveys" by either party. The first working level meeting was held in Beijing on 15 September 200o. Finally, on 13 February 2001 China and Japan agreed on a mutual prior notification system. According to Gao and Wu, the Agreement "cleverly" avoids specifying any line beyond which advance notification is required. It simply says that China is to give Japan at least two months' notice when its research ships plan to enter waters "near Japan and in which Japan takes interest" and that similarly, Japan is to inform China before its vessels enter waters "near" China. The notification must include the name of the organization conducting the research, the name and type of vessels involved, the responsible individual, the details of the research such as its purpose and equipment to be used, the planned length of the survey, and the areas to be surveyed. ${ }^{60}$

Substantive Obligation for Co-operation: Preferred Models/Types of Co-operative Arrangements in the East China Sea Region

\section{A South Korea-Japan Joint Development Agreement, 1974}

Between March 1969 and September 1970, altogether 11 seabed petroleum blocks were unilaterally staked out by Japan, South Korea, Taiwan and Okinawa (which was still under United States administration following the end of the Second World War). The four Japanese blocks and Okinawa's one were claimed by private oil interests, unlike South Korea's two and Taiwan's four by the respective governments. ${ }^{61}$

6o Zhiguo Gao and Jilu Wu, Key Issues in the East China Sea: A Status Report and Recommended Approaches, at 7-8, available at http://wilsoncenter.tv/sites/default/files.

61 Park Choon-Ho, Seabed Boundary Issues in the East China Sea, at 1, available at http:// wilsoncenter.tv/sites/default/files/Choon-Ho_Park_1_.pdf. 
The designated (joint development) area of the Agreement is specified in Article 2, paragraph 1 of the Agreement, as the sea area surrounded by, counter-clockwise from the northern tip, 1) the median line between Japan and Korea, 2) the median line between Japan and China, 3) the median line between Korea and China (that would be drawn if Japan is ignored), and 4) the limit claimed by Korea by reason of the natural prolongation of its continental shelf. Therefore, the sea area of joint development is only on the Japanese side of the median line between Japan and Korea. The designated joint development zone is then divided into small zones, each of which is explored and exploited by one or more developers approved by both States (Arts. 3 and 4). The approved developers of both States conclude a joint venture agreement and appoint an operation manager by agreement. The operation is conducted only by the operation manager (Arts. 5 and 6 ). A Japan-Korea Joint Committee is established, but is only a body for consultation about matters concerning the performance of the Agreement (Arts. 24 and 25). Each approved developer of both States is entitled to an equal share of the natural resources exploited in the joint development zone as profits earned from the joint development (Art. 9, para. 1). Reasonable costs for exploration and exploitation are equally allocated to the approved developers of both States. (Art. 9, para. 2).

Both States deem the part of the natural resources to which the approved developer of each State is entitled as natural resources exploited on the continental shelf over which the State has sovereign rights for the application of its domestic law (Art. 16), and tax only their respective approved developer (Art. 17). Both States apply their respective laws and regulations related to the exploration and exploitation of natural resources to small zones where their respective approved developer acts as a designated operation manager (Art. 19). It has been confirmed that no provision of this Agreement "shall be deemed to settle the issue of sovereign rights over the whole or part of the joint development zone or to harm the position of each contracting State with respect to the delimitation of the continental shelf" (Art. 28).

\section{B China-Japan Principled Consensus in the East China Sea, 2008}

China and Japan have overlapping jurisdictional claims in the East China Sea, which include seabed areas allegedly rich in hydrocarbon resources. China and Japan both claim sovereignty over the Senkaku/Diaoyu islands. Sovereignty over these islands affects the delimitation of the southern part of the East China Sea. China claims jurisdiction in the East China Sea based on the natural prolongation of its continental shelf and a 200 nautical mile $(\mathrm{nm}) \mathrm{EEz}$. In 2009 China submitted a claim to the UN Commission on the Limits of the Continental Shelf (UN-CLCS) that provided data supporting its claim to an 
extended continental shelf beyond $200 \mathrm{~nm}$, as far as the Okinawa Trough. Japan claims an EEZ as far as a median line that bisects the East China Sea, the coordinates of which it has never published. In its Eez law, Japan says that in the event of an overlap of claims, a median line should serve as the boundary. China has never recognized this median line.

Since 2005, some Japanese officials have suggested that Japan actually claims a full $200 \mathrm{~nm} \mathrm{EEZ}$, including space beyond the median line in the East China Sea. Some Japanese legal scholars have argued that the median line in the East China Sea was simply intended to be a provisional boundary until delimitation could be negotiated. However, Japan's stated opposition to China's development of the Chunxiao/Shirakaba field creates some confusion. When Japan protested Chinese activities at the Chunxiao/Shirakaba field in 2004 and 2005, it was on the basis that the gas field extends across the median line and, consequently, Japanese resources were being "stolen." The Japanese Ministry of Economy, Trade, and Industry (METI) commissioned a Norwegian survey vessel, the Ramform Victory, to prove this was the case. However, according to Manicom, ${ }^{62}$ if Japan did in fact claim an EEZ as far as $200 \mathrm{~nm}$, then it should have simply protested China's activities at the Chunxiao/Shirakaba field as a violation of Japan's EEz jurisdiction, since the Chunxiao/Shirakaba field is within $200 \mathrm{~nm}$ of Japan's coast. Japan did not do this. By implicitly recognizing that the Chunxiao/Shirakaba field is at least partially in Chinese waters, Japan has undermined somewhat its claim to a full $200 \mathrm{~nm}$ EEZ in that area.

In June 2008, Japanese and Chinese media reported that a breakthrough had been reached in the four-and-a-half year Chunxiao gas dispute. Rumors that an agreement was imminent had been circulating since early 2008 and had gained momentum during Hu Jintao's historic visit to Japan in May. The breakthrough followed eleven rounds of director-general level discussions, and several ministerial and executive level meetings. The elite commitment to arrive at a consensus emerged after a period of significant tension in the bilateral relationship. Given this turn around in bilateral relations, the process by which the "new consensus" emerged merits investigation as it may hold lessons for Sino-Japanese relations as a whole. ${ }^{63}$

62 See, Chris Acheson, Disputed Claims in the East China Sea (an interview with James Manicom), National Bureau of Asian Research, 25 July 2011, available at http://www.nbr.org/ downloads/pdfs/PSA/Interview_Maincom.pdf.

63 James Manicom, Sino-Japanese Cooperation in the East China Sea: Limitations and Prospects, 30 (3) Contemporary Southeast Asia 455-478 (2008). 
Foreign Ministry Spokesperson Jiang Yu announced on 18 June 2008 that China and Japan reached a principled consensus on the East China Sea issue through consultation on equal footing.

\section{Cooperation between China and Japan in the East China Sea}

In order to make the East China Sea, of which the delimitation between China and Japan is yet to be made, a "sea of peace, cooperation and friendship," China and Japan have, in keeping with the common understanding reached by leaders of the two countries in April 2007 and their new common understanding reached in December 2007, agreed through serious consultations that the two sides will conduct cooperation in the transitional period prior to delimitation without prejudicing their respective legal positions. The two sides have taken the first step to this end and will continue to conduct consultations in the future.

2. Understanding between China and Japan on Joint Development As the first step in the joint development of the East China Sea between China and Japan, the two sides will work on the following: (a) The block for joint development shall be the area that is bounded by straight lines joining the following points in the order listed. (b) The two sides will, through joint exploration, select by mutual agreement areas for joint development in the abovementioned block under the principle of mutual benefit. Specific matters will be decided by the two sides through consultations. (c) To carry out the abovementioned joint development, the two sides will work to fulfil their respective domestic procedures and arrive at the necessary bilateral agreement at an early date. (d) The two sides have agreed to continue consultations for the early realization of joint development in other parts of the East China Sea.

\section{Understanding on the Participation of Japanese Legal Person in the}

Development of Chunxiao Oil and Gas Field in Accordance with

Chinese Laws

Chinese enterprises welcome the participation of Japanese legal person in the development of the existing oil and gas field in Chunxiao in accordance with the relevant laws of China governing cooperation with foreign enterprises in the exploration and exploitation of offshore petroleum resources. The governments of China and Japan have confirmed this, and will work to reach agreement on the exchange of notes as necessary and exchange them at an early date. The two sides will fulfil their respective domestic procedures as required. 
Among the now well-known models or types of offshore co-operative arrangements established by neighbouring States around the world, certain common characteristics can now be discerned in the State practice in the East China Sea region. These common elements are as follows:

1. Unitization of individual fields/deposits appears to be preferred over the establishment of joint development zones corresponding to the overlapping claims areas of the interested States;

2. Involvement of domestic/local energy companies (especially national oil companies) is preferred over that of foreign-owned international oil companies; and

3. Success or failure of such co-operative arrangements is assessed as much (if not more) in the political domain as opposed to the economic benefits accruing from the development of hydrocarbon resources from these offshore wells. 